\title{
Recombinant human adenovirus-p53 improves the outcome of mid-late stage pancreatic cancer via arterial infusion
}

\author{
JINGGANG MO ${ }^{1,2^{*}}$, MEIHUA LIN ${ }^{3 *}$, BIN HE $^{4}, \mathrm{KAITAN}^{5}, \mathrm{CHONG} \mathrm{JIN}^{2}$, \\ $\mathrm{HAO}_{\mathrm{JANG}}{ }^{2}$, XUEFENG PAN ${ }^{2}$ and WEIDONG LIN ${ }^{2}$ \\ ${ }^{1}$ Department of Hepatobiliary Surgery, First Clinical College, Wenzhou Medical University, Wenzhou, \\ Zhejiang 325000; ${ }^{2}$ Department of Hepatobiliary Surgery, Taizhou Central Hospital, Taizhou, Zhejiang 318000; \\ ${ }^{3}$ Research Center of Clinical Pharmacy, State Key Laboratory for Diagnosis and Treatment of Infectious Disease, \\ First Affiliated Hospital, Zhejiang University, Hangzhou, Zhejiang 310003; Departments of ${ }^{4}$ Gastrointestinal Surgery and \\ ${ }^{5}$ Radiology, Taizhou Central Hospital, Taizhou, Zhejiang 325000, P.R. China
}

Received January 4, 2016; Accepted June 21, 2017

DOI: $10.3892 /$ ol.2017.7058

\begin{abstract}
The present study aimed to investigate the therapeutic efficacy and clinical value of recombinant human adenovirus-p53 (rAd-p53) perfusion via the pancreatic artery for the treatment of mid-late stage pancreatic cancer. rAd-p53 ( $2 \times 10^{12}$ virus particles) in $6 \mathrm{ml}$ normal saline was pushed (intravenous bolus) into the gastroduodenal and superior pancreaticoduodenal arteries via interventional superselection, with the catheter retained for subsequent drug administration at a 3-day interval for 4 cycles. Tumor changes in all patients were observed to evaluate tumor response by computed tomography (CT) at 2, 8 and 16 weeks post-treatment. The following improvements were noted in the 23-patient cohort: A total of $73.9 \%(17 / 23)$ of patients demonstrated significant tumor shrinkage $(>20 \%)$; the symptoms of abdominal and back pain were relieved in 15 patients; the survival time was $>12$ months in 1 patient and >6 months in 14 patients; the patient's general condition, including appetite, was improved in 13 patients; body weight was increased in 9 patients; jaundice was attenuated in 12 patients; and ascites subsided in 10 patients. However, the therapeutic outcome was poor in 2 patients whose tumors size did not show significant change after treatment as detected by CT. These 2 patients succumbed within 6 months. In conclusion, rAd-p53 perfusion via the pancreatic artery is a safe and minimally invasive option for the treatment of mid-late stage pancreatic cancer.
\end{abstract}

Correspondence to: Professor Jinggang Mo, Department of Hepatobiliary Surgery, Taizhou Central Hospital, 999 Donghai Avenue, Economic Development Zone, Taizhou, Zhejiang 318000, P.R. China

E-mail: mjg8882@163.com

*Contributed equally

Key words: recombinant human adenovirus-p53, pancreatic cancer, intervention therapy, computed tomography

\section{Introduction}

Advanced-stage pancreatic cancer is the most lethal human malignancy, with an overall 5-year survival rate of $<5 \%$ (1). This poor outcome is largely due to the late diagnosis, and as conventional therapeutics, including surgical resection, chemotherapy and radiotherapy, have limited efficacy (2). Although several strategies are widely used to treat advanced pancreatic cancer, such as using gemcitabine alone or in combination with other drugs, the emergence of drug resistance is becoming a problem for treating advanced pancreatic cancer $(3,4)$.

Cellular tumor antigen p53 (p53) is an important transcription factor that actives or represses the expression of numerous genes, including those involved in cell cycle and cell survival $(5,6)$. Previous studies have shown that p53 causes a significant antitumor effect inducing cell cycle arrest, senescence and apoptosis in response to stress stimulus such as oncogene activation and DNA damage (7-11). A recent study reported that $>75 \%$ of patients with advanced pancreatic cancer possessed a tumor protein p53 (TP53) gene alteration (12). Although there have been a number of widely reported adverse events, gene therapy is becoming a new paradigm and an important part of combined therapy regimens for tumors, and has shown enormous therapeutic potential (13-15). TP53 is by far the most commonly transferred tumor suppressor gene in cancer trials (16), but clinical trials based on wild-type TP53 in patients with pancreatic cancer are lacking.

The present study demonstrated that administration of recombinant human adenovirus p53 agent (rAd-p53) could not only reduce the size of the tumor, but also relieve the symptoms induced by pancreatic cancer.

\section{Patients and methods}

Patients and ethics statement. The present study was approved by the Ethics Committee of Taizhou Municipal Central Hospital (Taizhou, China) and conducted according to the Ethical Guidelines for Human Genome/Gene Research enacted by the Helsinki Declaration and the Chinese Government. Written informed consent was obtained from all patients. All 
Table I. Clinical features, treatment doses and outcomes of the 23 pancreatic cancer patients.

\begin{tabular}{|c|c|c|c|c|c|c|c|c|c|c|c|}
\hline $\begin{array}{l}\text { Case } \\
\text { no. }\end{array}$ & Sex & Age & Location & Size, $\mathrm{cm}$ & Jaundice & Pain & Lean & LM & $\mathrm{BM}$ & $\begin{array}{l}\text { rAdp53 } \\
\text { (vp) }\end{array}$ & $\begin{array}{c}\text { Shrinkage, } \\
\%\end{array}$ \\
\hline 1 & $\mathrm{~F}$ & 68 & Head & $4.6 \times 6.3$ & Yes & Yes & No & Yes & No & $8.0 \times 10^{12}$ & 26 \\
\hline 2 & $\mathrm{~F}$ & 79 & Body tail & $7.0 \times 4.3$ & No & No & Yes & No & Yes & $8.0 \times 10^{12}$ & 40 \\
\hline 3 & M & 73 & Head & $4.1 \times 3.6$ & No & Yes & Yes & No & No & $8.0 \times 10^{12}$ & 32 \\
\hline 4 & M & 50 & Head & $4.0 \times 2.7$ & Yes & Yes & No & No & No & $8.0 \times 10^{12}$ & 60 \\
\hline 5 & $\mathrm{~F}$ & 62 & Head & $9.0 \times 6.0$ & No & Yes & No & Yes & Yes & $8.0 \times 10^{12}$ & 43 \\
\hline 6 & M & 45 & Head & $4.3 \times 5.0$ & No & No & Yes & No & No & $8.0 \times 10^{12}$ & 50 \\
\hline 7 & M & 53 & Body tail & $13.7 \times 9.7$ & No & Yes & No & Yes & No & $8.0 \times 10^{12}$ & 58 \\
\hline 8 & M & 67 & Head & $3.4 \times 5.5$ & No & Yes & Yes & No & No & $8.0 \times 10^{12}$ & 0 \\
\hline 9 & $\mathrm{~F}$ & 82 & Head & $4.7 \times 3.4$ & Yes & Yes & No & No & No & $8.0 \times 10^{12}$ & 55 \\
\hline 10 & M & 47 & Head & $5.4 \times 4.2$ & Yes & Yes & No & No & No & $8.0 \times 10^{12}$ & 25 \\
\hline 11 & M & 63 & Head & $6.0 \times 5.3$ & Yes & Yes & Yes & No & No & $8.0 \times 10^{12}$ & 50 \\
\hline 12 & $\mathrm{~F}$ & 57 & Head & $4.7 \times 6.3$ & Yes & Yes & Yes & Yes & No & $8.0 \times 10^{12}$ & 32 \\
\hline 13 & M & 48 & Head & $5.6 \times 7.3$ & Yes & Yes & Yes & No & Yes & $8.0 \times 10^{12}$ & 0 \\
\hline 14 & M & 73 & Head & $4.9 \times 6.5$ & Yes & No & Yes & No & No & $8.0 \times 10^{12}$ & 40 \\
\hline 15 & M & 81 & Body & $4.6 \times 5.6$ & No & Yes & Yes & No & No & $8.0 \times 10^{12}$ & 50 \\
\hline 16 & $\mathrm{~F}$ & 75 & Head & $4.5 \times 6.3$ & Yes & Yes & Yes & No & No & $8.0 \times 10^{12}$ & 32 \\
\hline 17 & M & 57 & Body & $4.6 \times 5.8$ & No & Yes & Yes & No & Yes & $8.0 \times 10^{12}$ & 50 \\
\hline 18 & $\mathrm{M}$ & 74 & Body tail & $5.2 \times 6.7$ & No & Yes & Yes & Yes & No & $8.0 \times 10^{12}$ & 40 \\
\hline 19 & $\mathrm{M}$ & 68 & Head & $4.5 \times 5.2$ & Yes & Yes & Yes & No & No & $8.0 \times 10^{12}$ & 50 \\
\hline 20 & M & 71 & Head & $5.6 \times 6.8$ & Yes & Yes & No & No & Yes & $8.0 \times 10^{12}$ & 40 \\
\hline 21 & M & 86 & Body tail & $9.5 \times 8.3$ & No & Yes & Yes & No & No & $6.0 \times 10^{12}$ & 50 \\
\hline 22 & $\mathrm{M}$ & 56 & Body & $5.6 \times 4.2$ & No & No & No & No & No & $8.0 \times 10^{12}$ & 10 \\
\hline 23 & $\mathrm{M}$ & 61 & Head & $3.8 \times 6.0$ & No & Yes & No & No & No & $8.0 \times 10^{12}$ & 25 \\
\hline
\end{tabular}

rAd-p53, recombinant human adenovirus-p53; M, male; F, female; vp, virus particles; LM, lung metastasis; BM, bone metastasis.

23 cases of patients who did not receive surgical resection were collected between January 2010 and January 2012 at the Department of Hepatobiliary Surgery of Taizhou Central Hospital (Taizhou, China). None of the patients received local or systemic treatment prior to rAd-p53 treatment.

Treatment. First, the patient was laid flat in the digital subtraction angiography room for a celiac arteriography via the right femoral artery using the Seldinger method to identify the trunk of the celiac artery. The arteriography was superselected to the gastroduodenal artery in 18 cases, and to the superior pancreaticoduodenal artery in the remaining 5 cases. A total of $4 \mathrm{ml}$ rAd-p53 (2x10 ${ }^{12}$ virus particles; Gendicine ${ }^{\circledR}$; Benda Pharmaceutical, Inc., Wuhan, China) in $6 \mathrm{ml}$ normal saline was pushed (intravenous bolus) into each patient per cycle. After sealing the indwelling catheter with heparin, the patient was sent back to the ward. rAd-p53 was administered at a 3-day interval for a total of 4 cycles, so that a total dose of $8 \times 10^{12}$ virus particles were administered to each patient. Next, the perfusion catheter was removed and the incision was pressure-dressed locally.

Response evaluation. Temperature was checked three times daily, blood and urine routine three times per week, liver and kidney function was assessed three times per week, and pancreatic computed tomography (CT) was performed at 2, 8 and 16 weeks post-rAd-p53 administration.
Criteria for therapeutic effect evaluation. Therapeutic effect was graded as follows: i) Complete response (CR), disappearance of all visible lesions for at least 4 weeks; ii) partial response (PR), a $>50 \%$ decrease in the product of the maximum diameter and the maximum vertical diameter of the lesion for at least 4 weeks; iii) minimal response (MR), a $>25 \%$ and $<50 \%$ decrease in the product of the two diameters without occurrence of new lesions; iv) stable disease (SD), a $<25 \%$ decrease or a $<25 \%$ increase in the product of the two diameters without occurrence of new lesions; and v) progressive disease (PD), a $>25 \%$ increase in the product of the two diameters or occurrence of new lesions. The overall response rate was calculated as the CR plus the PR, without including MR and SD (17).

Statistical analysis. Statistical analysis was performed with GraphPad Prism 5.0 (GraphPad Software, La Jolla, CA, USA). Values are expressed as the mean \pm standard deviation. One-way analysis of variance was used to compare the differences between the groups using Dunnett's post hoc test. $\mathrm{P}<0.05$ was considered to indicate a statistically significant difference.

\section{Results}

Patient characteristics. The present study included 23 patients diagnosed with pancreatic cancer by biopsy, including 17 males and 6 females, with a mean age of 56.8 years (Table I). The time 
Table II. Therapeutic outcome evaluation.

\begin{tabular}{|c|c|c|c|c|c|}
\hline Outcome evaluation & $\mathrm{CR}(\%)$ & $\mathrm{PR}(\%)$ & $\operatorname{MR}(\%)$ & $\mathrm{SD}(\%)$ & $\mathrm{PD}(\%)$ \\
\hline At the end of treatment & $0(0.0)$ & $9(39.1)$ & $13(56.5)$ & $1(4.3)$ & $0(0.0)$ \\
\hline CT confirmation & $0(0.0)$ & $9(39.1)$ & $12(52.2)$ & $2(8.7)$ & $0(0.0)$ \\
\hline
\end{tabular}

Overall response rate $(\mathrm{CR}+\mathrm{PR})$ of $38.5 \%$. Percentages were calculated as previously described (17). CR, complete response; $\mathrm{PR}$, partial response; $\mathrm{MR}$, minimal response; $\mathrm{SD}$, stable disease; $\mathrm{PD}$, progressive disease; CT, computed tomography.

Table III. Changes in hematological profiles and liver/kidney function (mean \pm standard deviation).

\begin{tabular}{|c|c|c|c|c|c|c|c|c|c|}
\hline Time & $\begin{array}{l}\text { WBC, } \\
\times 10^{9} / 1\end{array}$ & $\begin{array}{l}\mathrm{RBC}, \\
\times 10^{12} / 1\end{array}$ & $\begin{array}{c}\mathrm{HB}, \\
\mathrm{g} / \mathrm{l}\end{array}$ & $\begin{array}{c}\mathrm{Pt} \\
\mathrm{x} 10^{12} / 1\end{array}$ & $\begin{array}{c}\text { SGPT, } \\
\mu / 1\end{array}$ & $\begin{array}{c}\text { Plasma } \\
\text { protein, } \\
\mathrm{g} / \mathrm{l}\end{array}$ & $\begin{array}{l}\text { Albumin, } \\
\mathrm{g} / \mathrm{l}\end{array}$ & $\begin{array}{l}\mathrm{BUN}, \\
\mathrm{mol} / \mathrm{l}\end{array}$ & $\begin{array}{c}\text { Bilirubin } \\
\text { level, } \\
\mu \mathrm{mol} / 1\end{array}$ \\
\hline Prior to treatment & $6.12 \pm 2.6$ & $445 \pm 44$ & $129 \pm 19$ & $256 \pm 130$ & $24 \pm 17$ & $71.6 \pm 73$ & $41.7 \pm 4.1$ & $5.3 \pm 1.0$ & $65.7 \pm 4.1$ \\
\hline After 1st injection & $8.16 \pm 4.6$ & $435 \pm 60$ & $128 \pm 18$ & $256 \pm 93$ & $19 \pm 6$ & $67.6 \pm 6.9$ & $38 \pm 4.9$ & $5.9 \pm 1.0$ & $56.3 \pm 4.1$ \\
\hline After 4th injection & $7.26 \pm 4.0$ & $425 \pm 84$ & $124 \pm 26$ & $308 \pm 14$ & $21 \pm 12$ & $69.8 \pm 8.6$ & $39.4 \pm 4.9$ & $4.8 \pm 1.5$ & $38.4 \pm 4.1^{\mathrm{a}}$ \\
\hline
\end{tabular}

${ }^{\mathrm{a}} \mathrm{P}<0.05$ vs. prior to treatment. WBC, white blood cell; RBC, red blood cell; HB, hemoglobin; Pt, platelets; SGPT, serum glutamic pyruvic transaminase; BUN, blood urea nitrogen.
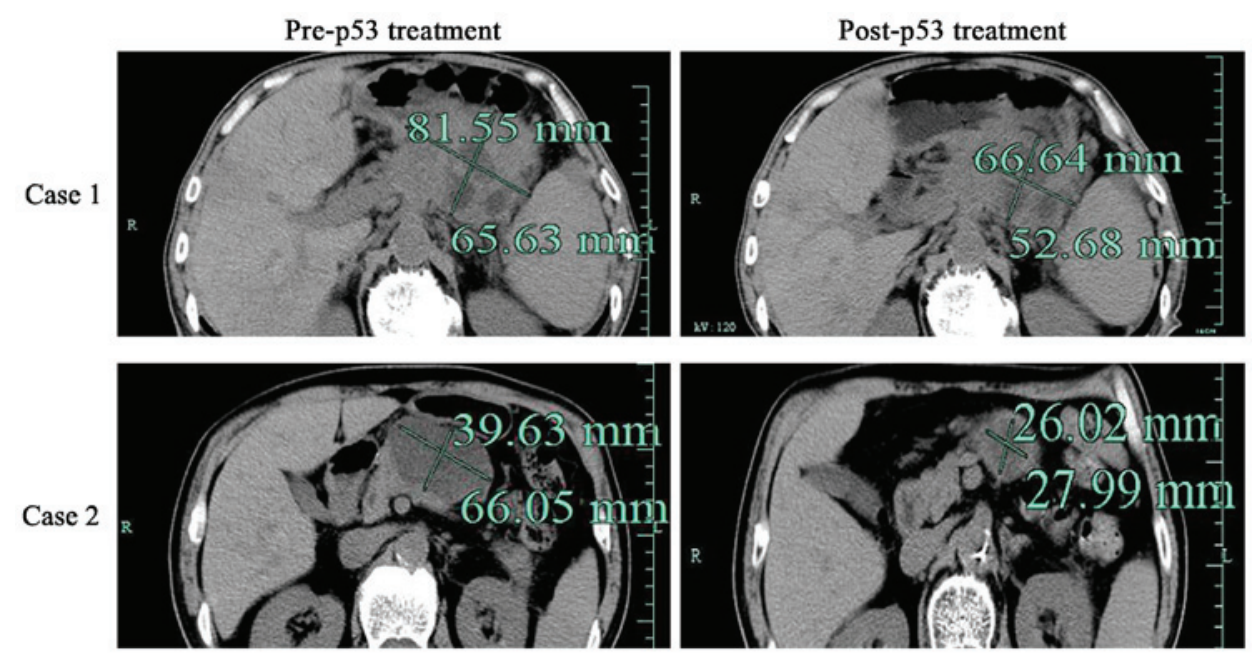

Figure 1. Computed tomography was used to assess the effect of adenovirus-mediated p53. Representative images of computed tomography in patients with pancreatic cancer prior to or following rAd-p53 treatment, as indicated. rAd-p53, recombinant human adenovirus-p53.

of disease onset was 6-18 months before diagnosis. All patients reported varying degrees of abdominal pain and radiating pain to the back on admission. Of the 23 patients, 19 patients presented with jaundice, 17 patients looked extremely lean, and 5 cases were complicated with lung metastasis and 3 with bone metastasis. Of the 23 pancreatic cancer cases, 15 cases were located in the head of the pancreas arising from the uncinate process, and the remaining 8 cases were located in the junction of the head and body.

Clinical outcome. Among the 23 pancreatic cancer patients (Table I), 17 patients experienced marked tumor shrinkage $(>20 \%), 14$ patients reported relief from the abdominal and back pain (Fig. 1 and Table II). The patient's general condition, including appetite, was improved in 13 patients, weight gain was reported in 9 patients, jaundice was lessened in 13 patients and ascites subsided in 10 patients (Table III). Clinical characteristics, including hematological profiles, and liver and kidney function, were not significantly different. The clinical outcome was poor in 2 patients, in whom a CT re-checkup showed no marked change in the tumor volume. These 2 patients succumbed within 6 months.

\section{Discussion}

Patients with pancreatic cancer, particularly mid-late stage pancreatic head cancer, often lose the opportunity for surgical intervention, while the therapeutic efficacy of chemotherapy 
and radiotherapy is usually unsatisfactory $(1,18)$. The prognosis of these patients is extremely poor due to advanced TNM stage and is often complicated with systemic jaundice, ascites, and intolerable abdominal and back pain (19).

The key to TP53 gene therapy lies in obtaining exogenous wild-type TP53, introducing it into tumor cells, and inducing its expression in the cells safely and effectively, usually using a virus, adenovirus or liposome as the vector (4). Current studies have demonstrated that introduction of wild-type TP53 into tumor cells can induce cell cycle arrest, promote apoptosis and inhibit tumor angiogenesis, so as to cause tumor cells of various origins to undergo apoptosis, eventually resulting in tumor disappearance (20-22).

Numerous studies have indicated that the expression of TP53 is altered and frequently mutated in pancreatic cancer, which may be associated with the more malignant biological behavior of the cancer (23-26). TP53 gene therapy, particularly adenovirus-mediated rAd-P53 gene therapy, has been used for the clinical treatment of head and neck squamous cell carcinoma, with good clinical outcomes, determined by increased survival times $(27,28)$. The arterial infusion approach can ensure that large amounts of the high-concentration drug can access to tumor cells, with only small amounts of the drug entering the circulation, thus maximizing the therapeutic efficacy and reducing the systemic adverse effects (29). Further laboratory tests showed that there were no significant side effects following adenovirus-mediated rAd-p53 gene therapy by the arterial infusion approach in terms of hematological profiles, and liver and kidney function. In the present study, the clinical symptoms were relieved in 21 of the 23 patients who received trans-arterial p53 perfusion therapy, suggesting that this method can be used clinically on a larger scale, although the number of cases in the study was relatively small and further clinical trials are required.

\section{References}

1. Nelson NJ: Pancreatic cancer research matures. J Natl Cancer Inst 99: 1432-1434, 2007.

2. Neoptolemos JP, Stocken DD, Bassi C, Ghaneh P, Cunningham D, Goldstein D, Padbury R, Moore MJ, Gallinger S, Mariette C, et al: Adjuvant chemotherapy with fluorouracil plus folinic acid vs gemcitabine following pancreatic cancer resection: A randomized controlled trial. JAMA 304: 1073-1081, 2010

3. Moore MJ, Goldstein D, Hamm J, Figer A, Hecht JR, Gallinger S, Au HJ, Murawa P, Walde D, Wolff RA, et al: Erlotinib plus gemcitabine compared with gemcitabine alone in patients with advanced pancreatic cancer: A phase III trial of the National Cancer Institute of Canada Clinical Trials Group. J Clin Oncol 25: 1960-1966, 2007.

4. Van Cutsem E, Vervenne WL, Bennouna J, Humblet Y, Gill S, Van Laethem JL, Verslype C, Scheithauer W, Shang A, Cosaert J and Moore MJ: Phase III trial of bevacizumab in combination with gemcitabine and erlotinib in patients with metastatic pancreatic cancer. J Clin Oncol 27: 2231-2237, 2009.

5. Riley T, Sontag E, Chen P and Levine A: Transcriptional control of human p53-regulated genes. Nat Rev Mol Cell Biol 9: 402-412, 2008.

6. Hirao A, Kong YY, Matsuoka S, Wakeham A, Ruland J, Yoshida H, Liu D, Elledge SJ and Mak TW: DNA damage-induced activation of $\mathrm{p} 53$ by the checkpoint kinase Chk2. Science 287: 1824-1827, 2000.

7. Sakaguchi K, Herrera JE, Saito S, Miki T, Bustin M, Vassilev A, Anderson CW and Appella E: DNA damage activates p53 through a phosphorylation-acetylation cascade. Genes Dev 12: 2831-2841, 1998.

8. Collado M and Serrano M: Senescence in tumours: Evidence from mice and humans. Nat Rev Cancer 10: 51-57, 2010.
9. Kastan MB, Canman CE and Leonard CJ: P53, cell cycle control and apoptosis: Implications for cancer. Cancer Metastasis Rev 14: 3-15, 1995

10. Ghaneh P, Greenhalf W, Humphreys M, Wilson D, Zumstein L, Lemoine NR and Neoptolemos JP: Adenovirus-mediated transfer of p53 and p16(INK4a) results in pancreatic cancer regression in vitro and in vivo. Gene Ther 8: 199-208, 2001.

11. Wu J, Zhu Y, Xu C, Xu H, Zhou X, Yang J, Xie Y and Tao M: Adenovirus-mediated p53 and ING4 gene co-transfer elicits synergistic antitumor effects through enhancement of p53 acetylation in breast cancer. Oncol Rep 35: 243-252, 2016.

12. Rosenfeldt MT, O'Prey J, Morton JP, Nixon C, MacKay G, Mrowinska A, Au A, Rai TS, Zheng L, Ridgway R, et al: p53 status determines the role of autophagy in pancreatic tumour development. Nature 504: 296-300, 2013.

13. Weill D, Mack M, Roth J, Swisher S, Proksch S, Merritt J and Nemunaitis J: Adenoviral-mediated p53 gene transfer to non-small cell lung cancer through endobronchial injection. Chest 118: 966-970, 2000.

14. Ginn SL, Alexander IE, Edelstein ML, Abedi MR and Wixon J: Gene therapy clinical trials worldwide to 2012 - an update. J Gene Med 15: 65-77, 2013.

15. Merritt JA, Roth JA and Logothetis CJ: Clinical evaluation of adenoviral-mediated p53 gene transfer: Review of INGN 201 studies. Semin Oncol 28 (5 Suppl 16): S105-S114, 2001.

16. Vousden $\mathrm{KH}$ and Prives C: Blinded by the light: The growing complexity of p53. Cell 137: 413-431, 2009.

17. Wolchok JD, Hoos A, O'Day S, Weber JS, Hamid O, Lebbé C, Maio M, Binder M, Bohnsack O, Nichol G, et al: Guidelines for the evaluation of immune therapy activity in solid tumors: Immune-related response criteria. Clin Cancer Res 15: 7412-7420, 2009.

18. Hidalgo M: Pancreatic cancer. N Engl J Med 362: 1605-1617, 2010.

19. Jemal A, Siegel R, Xu J and Ward E: Cancer statistics, 2010. CA Cancer J Clin 60: 277-300, 2010.

20. Liu TJ, Zhang WW, Taylor DL, Roth JA, Goepfert H and Clayman GL: Growth suppression of human head and neck cancer cells by the introduction of a wild-type p53 gene via a recombinant adenovirus. Cancer Res 54: 3662-3667, 1994.

21. Shimada H, Shimizu T, Ochiai T, Liu TL, Sashiyama H, Nakamura A, Matsubara H, Gunji Y, Kobayashi S, Tagawa M, et al: Preclinical study of adenoviral p53 gene therapy for esophageal cancer. Surg Today 31: 597-604, 2001.

22. Lang FF, Bruner JM, Fuller GN, Aldape K, Prados MD, Chang S, Berger MS, McDermott MW, Kunwar SM, Junck LR, et al: Phase I trial of adenovirus-mediated p53 gene therapy for recurrent glioma: Biological and clinical results. J Clin Oncol 21: 2508-2518, 2003

23. Ternovoi VV, Curiel DT, Smith BF and Siegal GP: Adenovirusmediated p53 tumor suppressor gene therapy of osteosarcoma. Lab Invest 86: 748-766, 2006.

24. Scarpa A, Capelli P, Mukai K, Zamboni G, Oda T, Iacono C and Hirohashi S: Pancreatic adenocarcinomas frequently show p53 gene mutations. Am J Pathol 142: 1534-1543, 1993.

25. Tomaszewska R, Karcz D and Stachura J: An immunohistochemical study of the expression of bcl-2 and p53 oncoproteins in pancreatic intraepithelial neoplasia and pancreatic cancer. Int J Pancreatol 26: 163-171, 1999.

26. Weissmueller S, Manchado E, Saborowski M, Morris JP IV, WagenblastE, Davis CA, Moon SH, Pfister NT, Tschaharganeh DF, Kitzing T, et al: Mutant p53 drives pancreatic cancer metastasis through cell-autonomous PDGF receptor $\beta$ signaling. Cell 157: 382-394, 2014.

27. Zhang SW, Xiao SW, Liu CQ, Sun Y, Su X, Li DM, Xu G, Cai Y, Zhu GY, Xu B and Lü YY: Treatment of head and neck squamous cell carcinoma by recombinant adenovirus-p53 combined with radiotherapy: A phase II clinical trial of 42 cases. Zhonghua Yi Xue Za Zhi 83: 2023-2083, 2003 (In Chinese).

28. Nemunaitis J, Swisher SG, Timmons T, Connors D, Mack M, Doerksen L, Weill D, Wait J, Lawrence DD, Kemp BL, et al: Adenovirus-mediated p53 gene transfer in sequence with cisplatin to tumors of patients with non-small-cell lung cancer. J Clin Oncol 18: 609-622, 2000.

29. Li N, Zhou J, Weng D, Zhang C, Li L, Wang B, Song Y, He Q, Lin D, Chen D, et al: Adjuvant adenovirus-mediated delivery of herpes simplex virus thymidine kinase administration improves outcome of liver transplantation in patients with advanced hepatocellular carcinoma. Clin Cancer Res 13: 5847-5854, 2007. 